\title{
A Study on the Influence of Fly Ash and Nano- Silica on Strength Properties of Concrete
}

\author{
M. Guru Prasad ${ }^{1}$, K. Rajasekhar ${ }^{2}$ \\ ${ }^{1}$ M. Tech Research Scholar in Siddartha Educational Academy Group of Institutions, Tirupati, India \\ ${ }^{2} \mathrm{PhD}$ Professor of Siddartha Educational Academy Group of Institutions
}

\begin{abstract}
The cement consumption is directly related to the country's infrastructure sector and thus growth is paramount in determining the development of the country. With a current production capacity of around 366 million tonnes (MT), India is the second largest producer of cement in the world. Environmental standpoint cement has a negative impact, because manufacturing it emits about a ton of greenhouse gas $\left(\mathrm{CO}_{2}\right)$ into the atmosphere for every ton of cement manufactured. Production of Portland cement not only releases $7 \%$ of the World's carbon dioxide, the cement industry also uses a lot of natural resources such as limestone, clay, petroleum, coal and other substances to preserve the natural resources and to reduce the pollution due to the production of cement is by limiting the cement content in the concrete without compromising the strength. There were efforts before to partially replace cement in concrete with new compounds and industry by-products. The aim of the present experimental investigation is to find the influence of combined application of Nano-Silica (NS) and Fly Ash (FA) on the strength properties of concrete. Fly Ash and Nano-Silica are used as partial replacement of cement. In the present experimental investigation the cement is partially replaced by $20 \%$ and $30 \%$ of Fly Ash and $1.5 \%$, $3 \%$ and $4.5 \%$ of Nano-Silica by weight. The effect of combined application of Fly Ash and Nano-Silica on compressive strength, split tensile strength, flexural strength and modulus of elasticity of M25 grade of concrete are investigated. The test results of concrete prepared using the combination of different proportions of Fly Ash and Nano-Silica are compared with that of controlled concrete. The variation of different test results of concrete prepared with various proportions of Fly Ash and Nano-Silica indicates the same trend. Based on the test results, it can be observed that concrete prepared with $20 \%$ Fly Ash and $3 \%$ Nano-Silica combination possesses improved strength properties compared to the controlled concrete. The increase in the various strength characteristics of concrete prepared using Fly Ash and Nano-Silica can be attributed to the effective particle packing and also the availability of additional binder in the presence of Fly-Ash and Nano-Silica.
\end{abstract}

Keywords: Cement, Greenhouse Gas, Nano-Silica, Fly-Ash, Compressive Strength, Split Tensile Strength, Flexural Strength, Modulus of Elasticity

\section{Introduction}

\subsection{General}

Cement can be considered as the most generally utilized material as a part of the development business. In the present day development hone, alongside the quality equivalent significance is given to the solidness of cement. The Indian Standard Code of practice for plain and strengthened cement prescribes the base bond substance to fulfill the quality and solidness prerequisites. Consequently, the use of concrete is expanded. Be that as it may, the concrete generation expends expansive measure of vitality and transmits carbon dioxide results in natural contamination. Henceforth, one of the answers for these issues is to decrease the utilization of bond and use Pozzolana materials for the planning of cement. Past studies demonstrates that the utilization of Fly-Ash (FA), Micro Silica (MS), Metakaoline (MK) and Ground Granulated Blast Furnace Slag (GGBS) as halfway substitution of bond decreases the bond utilization furthermore expands the quality and sturdiness of cement. To enhance the execution of cement further, Nano materials are likewise now being presented as supplementary materials.

It has been above 70 years to examine and utilize fly fiery debris. With its application, the activity instrument of fly slag has been perceived. Amid the beginning stage, just its pozzolanic movement is focused. Numerous analysts gave themselves to the exploration of the potential action of fly fiery debris and the hydration procedure of fly powder bond.
With the developing of the cognizance for fly fiery debris properties, it can be watched that the particles of fly slag have the morphology that is distinctive to other pozzolanic materials as appeared in Figure 1.1.

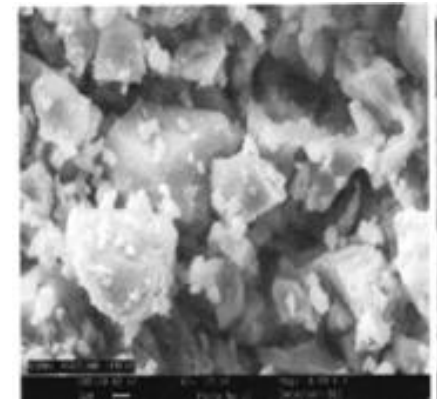

(a) Portland Cement Figure 1.1: SEM micrographs $(8,000 \mathrm{xs}$

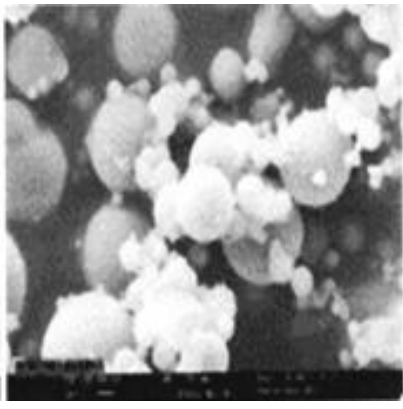

(b) Fly Ash
It is the one of kind molecule morphology to make it have the capacity decreasing water, which other pozzolanic materials don't have. It impacts the rheological property of new ortar as well as the introductory structure of solidified concrete stone.

The morphological impact implies that in solid, mineralpowdered materials create the impact because of the morphology, structure and surface property of the molecule and the molecule size appropriation. From the impact of fly cinder on the properties of bond based materials, the morphology impact incorporates three angles: filling, greasing up and well circulating. These parts rely on upon 


\section{International Journal of Science and Research (IJSR) \\ ISSN (Online): 2319-7064 \\ Index Copernicus Value (2013): 6.14 | Impact Factor (2015): 6.391}

the shape, size dissemination, and so on., of fly powder and impact numerous properties of cement.

The particular change lies in the accompanying angles:

1) Incorporating FA by the system for super-substituting, a broadly utilized outline technique, adequately expands the aggregate sum of fastener in cement and makes it less demanding to reduced.

2) Substituting Fly Ash for a piece of bond in cement can strikingly diminish the amount of warmth created by concrete hydration.

\subsection{Objectives}

The goals of the present examination work are to concentrate on the

1) Effect of Fly fiery remains content on compressive quality, split rigidity, modulus of flexibility and flexural quality of cement.

2) Effect of joined use of Nano-Silica and Fly fiery debris on compressive quality improvement split rigidity, modulus of versatility and flexural quality.

3) Comparison of the consequences of Conventional Concrete, with consolidated utilization of Fly slag and Nano-Silica as substitution of Cement.

\subsection{Scope}

The extent of venture work is

1) Preliminary lab tests on bond, fine total and coarse total.

2) Mix outline and proportioning of elements of Concrete.

3) Water to fastener (Cement +Fly Ash) proportion was considered as 0.50 .

4) $150 \mathrm{~mm} \times 150 \mathrm{~mm} \times 150 \mathrm{~mm}$ size blocks were thrown and cured for pressure testing for the determination of the Properties of cements at 3, 7, 28 and 56 Days.

5) Content of the Fly Ash utilized as $20 \%$ and $30 \%$ of the aggregate cementitious material.

6) Dosages of the Nano Silica utilized are $1.5 \%, 3 \%$ and $4.5 \%$ of the aggregate cementations material.

\section{Literature Review}

\subsection{General}

These days the solid analysts and clients are exploiting auxiliary cementitious materials to give cement of more noteworthy qualities. One of the freshest innovations to break into the solid condescend range is the utilization of industry by-items nano-particles in the solid network. By utilizing modern by-items nano-particles, the improvement of the quality bearing precious stones of concrete glue can be expanded. A system to decrease the bond content in cement blends is the utilization of fly fiery debris and nanosilica.

The examinations conveyed by different analysts on the utilization of fly cinder and nano-silica are introduced here.

JAGADESH.SUNKU (2006) had contemplated the upsides of utilization of fly powder as Supplementary Cementing Material (SCM) in Fiber concrete sheets. Fly powder containing fiber bond sheets shows low early quality even at an ideal dose of $10-20 \%$.

D.P. BENTZ et. al.(2010) contemplated the assessment of maintainable high volume fly fiery debris cements. The outcomes were contrasted and the controlled concrete and mass substitutions of bond by fly Ash somewhere around $15 \%$ and $75 \%$ and an objective drop of $200 \mathrm{~mm} \pm 20 \mathrm{~mm}$. The aggregate water substance was minimized through the utilization of an ideal Super Plasticizer measurements that brought about water diminishments of $1 \% 150 \%$ and $11 \%$ separately for the reference blends of $\mathrm{w} / \mathrm{b}=0.5, \mathrm{w} / \mathrm{b}=0.55$, and, $w / b=0.6$ which prompts the same rate decreases of bond. Compressive quality or splitting rigidity at an age of 28 days.

Vanitha Aggarwal et. al. (2010) considered the solid solidness through high volume fly cinder cement. The outcomes demonstrated that fly cinder in cement diminishes the compressive quality at ahead of schedule ages yet there is an exceptional increment in the compressive quality at later ages. The solid with more than $40 \%$ substitution of bond show lesser 28 days quality however increases better quality at 90 days or later.

G. Carette et.al. (2010) examined on the early age quality improvement of cement fusing fly fiery remains and consolidated silica smolder. Early-age quality improvement of cement in which part of the portland bond has been supplanted by low-calcium fly fiery remains has a tendency to be moderate, in light of the fact that fly powder goes about as a generally inactive segment amid this time of hydration, however at later ages it contribute altogether to quality advancement. It was viewed as that the issue of low early-age quality of Portland bond fly slag cement could be overcome by the joining of little measures of consolidated silica rage, a fine and all the more quickly reactive pozzolan. This report shows the consequences of an examination on the early-age quality improvement of cement consolidating $30 \%$ low-calcium fly cinder, and to which little measures of candened silica seethe have been included.

George Querciaet. al. (2012) concentrated on the impacts of nebulous nano-silica increments on mechanical and strength execution of SCC blends. It has been accounted for that nano-silica $(\mathrm{nS})$ expansion expands the Compressive Strength and lessens the general penetrability of solidified cement because of the pozzolanic properties which are bringing about better hydrated stages (C-S-H gel) and densified microstructure (nano-filler and Anti - Leaching impacts). These impacts upgrade the sturdiness of solid structures, for example, spans, quays or seaward oil offices in marine situations. In this study two distinct sorts of nano silica were connected in self-compacting concrete (SCC), both having comparable molecule size dispersions (PSD) yet delivered in two unique procedures (raged powder silica and encouraged silica in colloidal suspension). The impact of Nano Silica on SCC was explored concerning the properties of cement in the crisp state (workability) and solidified state (mechanical properties and toughness).

B.W. Langan et. al. (2012) concentrated on the impact of silica smoke and fly Ash on warmth of hydration of Portland 


\section{International Journal of Science and Research (IJSR) \\ ISSN (Online): 2319-7064 \\ Index Copernicus Value (2013): 6.14 | Impact Factor (2015): 6.391}

concrete. Aftereffects of calorimeter tests on Portland concrete silica-seethe fly fiery debris blends are exhibited. Information demonstrate that silica seethe quickens concrete hydration at high water/cementitious proportions and impedes hydration at low water/cementitious proportions. Then again, fly fiery debris hinders concrete hydration all the more essentially at high water/cementitious proportions. At the point when silica seethe and fly fiery remains are included with concrete, the reactivity of the silica smoke is hampered and the hydration of the cementitious framework is essentially hindered. W/C:0.35,0.40,0.50.

Kazim Turk et. al. (2012) considered the impact of fly fiery remains and silica rage on compressive quality, Sorptivity and carbonation of SCC. Class F fly Ash (FA) at 25\%, 30\%, $35 \%$ and $40 \%$ and Silica Fume (SF) at 5\%, 10\%, 15\% and $20 \%$ substitution of Portland Cement (PC) CEM 142.5 in SCC was utilized to e aluate the impact of sorts and amount of powder augmentations on compressive quality and saturations properties of SCC.

Thomas et al. (1999) reported that fly cinder diminished solid quality at ahead of schedule. ages, however altogether improved quality at later ages. Then again, solid quality was fundamentally expanded by utilizing silica smolder, particularly at ahead of schedule ages, and the rate of quality advancement at later ages for silica seethe concrete and plain Portland bond cement was comparative. Along these lines, the creators called attention to that silica rage and fly fiery remains mix brought about enhanced early age and long haul quality improvement of cement.

\section{Material Properties}

\subsection{General}

Cement is a development material made out of Portland bond, sand, smashed stone and water. The concrete and water shape a glue which solidifies by concoction response into a solid, stone-like mas. 0 more bond glue ought to be utilized than would normally be appropriate to coat all the total surfaces and to fill every one of the voids.

The solid glue is plastic and effectively shaped into any structure or trowelled to deliver a smooth surface. Solidifying starts quickly, however safeguards are taken, for the most part by covering, to maintain a strategic distance from fast loss of dampness since the vicinity of water is important to proceed with the substance response and increa e the quality. An excess of water, in any case, delivers a solid that is more permeable and weaker. The nature of the glue framed by the bond and water to a great extent decides the character of the solid. Proportioning of the elements of cement is alluded to as planning the blend. Cement might be created as a thick mass which is for all intents and purposes manufactured rock, and chemicals might be added to make it waterproof, or it can be made permeable and exceptionally penetrable for such use as channel beds.

An air-entraining synthetic might be added to create minute rises for porosity or light weight. The slow increment in quality is because of the hydration of the Tricalcium aluminates and silicates. Sand utilized as a part of cement was initially indicated as generally precise, yet adjusted grains are presently favored. The stone is typically pointedly broken. The unit weight of cement fluctuates with the sort and measure of rock and sand. A solid with trap rock might have a thickness of $2,483 \mathrm{~kg} / \mathrm{m} 3$. Cement is more grounded in pressure than in tensin, and steel bar, called rebar or cross section is inserted in auxiliary individuals to build the malleable and flexural Strengths. Notwithstanding the basic uses, cement is generally utilized as a part of precast units, for example, piece, tile, sewer, and water funnel, and elaborate items. The following table represents the properties of cement, fine aggregate, Corse aggregate.

Table 3.1: Properties of Cement

\begin{tabular}{|c|c|c|}
\hline S. & Property & Values \\
No & & \\
\hline 1. & Specific Gravity & 3.15 \\
\hline 2. & Normal Consistency & $33 \%$ \\
\hline 3. & Setting Time & \\
\hline & i) Initial Setting time & 40 mins \\
& ii) Final setting time & \\
\hline
\end{tabular}

Table 3.2: Properties of Fine Aggregate

\begin{tabular}{|c|l|c|}
\hline S.No & \multicolumn{1}{|c|}{ Property } & Values \\
\hline 1. & Specific Gravity & 2.60 \\
\hline 2. & Fineness Modulus & 2.8 \\
\hline 3. & Bulk Density & \\
\hline & i. Loose State & $15.75 \mathrm{kN} / \mathrm{m}^{3}$ \\
\hline & ii. Compacted State & $17.05 \mathrm{kN} / \mathrm{m}^{3}$ \\
\hline 4. & Grading of Sand & Zone - II \\
\hline
\end{tabular}

Table 3.4: Properties of coarse Aggregate

\begin{tabular}{|c|l|c|}
\hline S.No & \multicolumn{1}{|c|}{ Property } & Values \\
\hline 1. & Specific Gravity & 2.61 \\
\hline 2. & Bulk Density & \\
\hline & i. Loose State & $14.13 \mathrm{kN} / \mathrm{m}^{3}$ \\
\hline & ii. Compacted State & $16.88 \mathrm{kN} / \mathrm{m}^{3}$ \\
\hline 3. & Water Absorption & $0.4 \%$ \\
\hline 4. & Fineness Modulus & 7.2 \\
\hline
\end{tabular}

\subsection{Water}

Water fit for drinking is by and large thought to be fit for making concrete. Water ought to be free from acids, oils, alkalies, vegetables or other natural Impurities. Delicate waters additionally deliver weaker cement. Water has two capacities in a solid blend. Firstly, it responds with the concrete to frame bond glue in which the dormant totals are held in suspension until the concrete glue has solidified. Besides, it serves as a vehicle or oil in the blend of fine totals and bond.

Table 3.5: Properties of Fly Ash

\begin{tabular}{|c|c|c|}
\hline S.No. & Ingredient & Value \\
\hline 1. & Silica $\left(\mathrm{SiO}_{2}\right)$ & $56.88 \%$ \\
\hline 2. & Aluminumtrioxide $\left(\mathrm{Al}_{2} \mathrm{O}_{3}\right)$ & $27.65 \%$ \\
\hline 3. & Ferric oxide $\left.\left.\left(\mathrm{Fe}_{2} \mathrm{O}\right)+\mathrm{Fe}\right) \mathrm{O}_{4}\right)$ & $6.28 \%$ \\
\hline 4. & Titanium dioxide $\left(\mathrm{TiO}_{2}\right)$ & $0.31 \%$ \\
\hline 5. & Calcium oxide $(\mathrm{Cao})$ & $3.6 \%$ \\
\hline 6. & Magnesium oxide $(\mathrm{MgO})$ & $0.34 \%$ \\
\hline 7. & Sulphate $\left(\mathrm{SO}_{4}\right)$ & $0.27 \%$ \\
\hline 8. & Loss of ignition $(\mathrm{LOI})$ & $4.46 \%$ \\
\hline 9. & Specific gravity of Fly Ash & 2.12 \\
\hline
\end{tabular}

\section{Volume 5 Issue 6, June 2016 www.ijsr.net}




\section{International Journal of Science and Research (IJSR) \\ ISSN (Online): 2319-7064 \\ Index Copernicus Value (2013): 6.14 | Impact Factor (2015): 6.391}

\subsection{Nano-Silica}

Nano-silica is another pozzolanic material in type of water emulsion of colloidal silica. It has all the earmarks of being possibly superior to anything silica-smolder because of higher substance of indistinct silica $(>99 \%)$ and the decreased size of its circular particles (1-50 nm). In this trial program bond is supplanted by $1.5 \%, 3 \%$ and $4.5 \%$ of Nano silica. The properties of nano-silica are appeared in Table 3.6 and Fig 3.3 demonstrates the nano-silica test utilized for Concrete arrangement.

Table 3.6: Properties of Nano Silica

\begin{tabular}{|c|l|l|}
\hline S.No. & Characteristics & Actual Analysis \\
\hline 1. & Nano solids & $39.5-41 \%$ \\
\hline 2. & $\mathrm{Ph}$ & $9.0-10$ \\
\hline 3. & Specific Gravity & $1.29-1.31$ \\
\hline 4. & Texture & Milky White Liquid \\
\hline 5. & Dispersion & Water \\
\hline
\end{tabular}

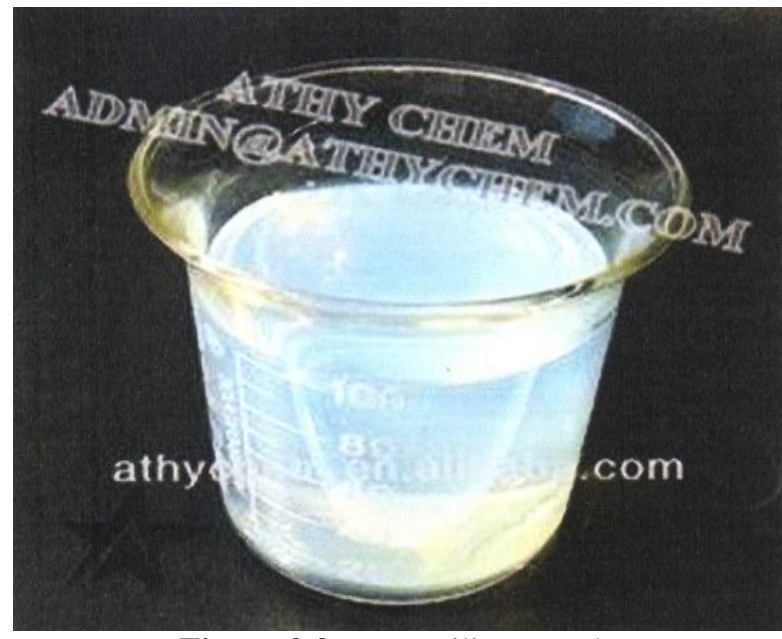

Figure 3.3: Nano-silica sample

\section{Mix Design}

\subsection{General}

The procedure of selecting suitable elements of concrete and deciding their relative sums with the target of delivering a solid of the required workability, quality, toughness as monetarily as could reasonably be expected, is termed as the solid blend plan. The proportioning of element of cement is administered by the required execution of cement in two states, in particular the plastic and the solidified states. On the off chance that the plastic cement is not workable, it can't be legitimately set and compacted. The property of workability, in this manner, happens to essential significance.

The Compressive Strength of solidified solid which is for the most part thought to be a record of its different properties, relies on numerous variables, e.g. quality and amount of bond, water and totals; bunching and blending; putting, compaction and curing. The expense of cement is gotten from the expense of materials, plant and work. The varieties in the expense of materials emerge from the way that the concrete is a few times excessive than the total.
The real cost of cement is identified with the expense of materials required for delivering a base mean quality called trademark quality. This relies on upon the quality control measures, yet there is doubtlessly the quality control adds to the expense of cement. The degree of value control is regularly a financial trade off, and relies on upon the size and sort of employment. The expense of work relies on upon the workability of blend, e.g., a solid blend of lacking workability might bring about a high cost of work to acquire a level of compaction with accessible gear.

\subsection{Design Mix}

\section{Requirements of concrete mix design:}

The prerequisites which shape the premise of determination and proportioning of blend fixings are:

a) The least Compressive Strength required from auxiliary thought

b) The satisfactory workability important for full compaction.

c) Maximum water-bond proportion and concrete substance to give satisfactory solidness.

Factors affecting the choice of mix proportions

The various factors affecting the mix design are:

\section{i) Compressive Strength}

It is a standout amongst the most critical properties of cement and impacts numerous different properties of the solidified cement. The mean Compressive Strength required at a particular age, as a rule 28 days, decides the ostensible water-concrete proportion of the blend. The other variable influencing the quality of cement at a given age and cured at a recommended temperature is the level of compaction. By law the quality of completely compacted cement is contrarily corresponding to the water-bond proportion.

\section{ii) Workability}

The level of workability required relies on upon three elements. These are the extent of the area, the measure of support, and the system for compaction to be utilized. For the slender and conjested fortified area or unavailable parts, the solid must have a high workability so that full compaction can be accomplished with a sensible measure of exertion. This additionally applies to the inserted steel segments. The sought workability relies on upon the compacting hardware.

\section{iii) Durability}

The strength of cement is its imperviousness to the forceful ecological conditions. High quality cement is for the most part more tough than low quality cement. In the circumstances when the high quality is redundant but rather the states of presentation are such that high strength is basic, the toughness prerequisite will decide the water-bond proportion to be utilized.

\section{iv) Maximum nominal size of aggregate}

When all is said in done, bigger the most extreme size of total, littler is the bond necessity for a specific water-bond proportion, on the grounds that the workability of solid increments with expansion in greatest size of the total. IS 


\section{International Journal of Science and Research (IJSR) \\ ISSN (Online): 2319-7064 \\ Index Copernicus Value (2013): 6.14 | Impact Factor (2015): 6.391}

456:2000 and IS 1343:1980 suggest that the ostensible size of the total ought to be as huge as would be prudent.

\section{v) Grading and type of aggregate}

The grading of aggregate influences the mix proportions for a specified workability and water-cement ratio. Coarser the grading leaner will be the mix which can be used. Very lean mix is not desirable since it does not contain enough finer material to make the concrete cohesive.

The type of aggregate influences strongly the aggregatecement ratio for the desired workability and stipulated water cement ratio. An important feature of a satisfactory aggregate is the uniformity of the grading which can be achieved by mixing different size fractions.

\section{vi) Quality Control}

The level of control can be assessed measurably by the varieties in test outcomes. The variety in quality results is because of the varieties in the properties of the blend fixings and absence of control of precision in clustering, blending, putting, curing and testing. The component controlling this distinction is termed as quality control

\subsection{Mix Design for M25 Grade of Concrete}

Table 4.1: Stipulations for proportioning ofM25 grade concrete

\begin{tabular}{|c|c|}
\hline Type of Cement & OPC 43 Grade \\
\hline Maximum Nominal size of Aggregate & $20 \mathrm{~mm}$ \\
\hline Minimum content of Cement & $320 \mathrm{~kg} / \mathrm{m}^{3}$ \\
\hline Maximum Water Cement ratio & 0.50 \\
\hline Specific Gravity of Cement & 3.15 \\
\hline Specific Gravity of Fine aggregate & 2.60 \\
\hline Specific Gravity of Coarse aggregate & 2.61 \\
\hline
\end{tabular}

Table 4.2: Mix Proportions for M25 Grade Concrete

\begin{tabular}{|c|c|c|c|c|c|c|c|c|c|}
\hline S. No & $\begin{array}{c}\text { Cement } \\
(\%)\end{array}$ & $\begin{array}{c}\text { Fly } \\
\text { Ash } \\
(\%)\end{array}$ & $\begin{array}{c}\text { Nano- } \\
\text { Silica } \\
(\%)\end{array}$ & $\begin{array}{c}\text { Water } \\
(\mathrm{l})\end{array}$ & $\begin{array}{c}\text { Cement } \\
(\mathrm{kg})\end{array}$ & $\begin{array}{c}\text { Fly } \\
\text { Ash } \\
(\mathrm{kg})\end{array}$ & $\begin{array}{c}\text { Colloidal } \\
\text { Nano-Silica } \\
(\mathrm{kg})\end{array}$ & $\begin{array}{c}\text { Fine } \\
\text { Aggregate } \\
(\mathrm{kg})\end{array}$ & $\begin{array}{c}\text { Coarse } \\
\text { Aggregate } \\
(\mathrm{kg})\end{array}$ \\
\hline 1 & 100 & 0 & 0 & 160 & 320 & 0 & 0 & 725 & 1220 \\
\hline 2 & 80 & 20 & 0 & 160 & 256 & 64 & 0 & 725 & 1220 \\
\hline 3 & 78.5 & 20 & 1.5 & 152.8 & 251.2 & 64 & 12 & 725 & 1220 \\
\hline 4 & 77 & 20 & 3 & 145.6 & 246.4 & 64 & 24 & 725 & 1220 \\
\hline 5 & 75.5 & 20 & 4.5 & 138.4 & 241.6 & 64 & 36 & 725 & 1220 \\
\hline 6 & 70 & 30 & 0 & 160 & 224 & 96 & 0 & 725 & 1220 \\
\hline 7 & 68.5 & 30 & 1.5 & 152.8 & 219.2 & 96 & 12 & 725 & 1220 \\
\hline 8 & 67 & 30 & 3 & 145.6 & 214.4 & 96 & 24 & 725 & 1220 \\
\hline 9 & 65.5 & 30 & 4.5 & 138.4 & 209.6 & 96 & 36 & 725 & 1220 \\
\hline
\end{tabular}

By the above mixed proportion calculation its state that for M25 Grade $320 \mathrm{~kg}, 725 \mathrm{~kg}, 1220 \mathrm{~kg}$ of Cement, Fine aggregate, Coarse aggregate respectively with $160 \mathrm{~L}$ of water were obtained. By replacing the cement with $20 \%, 30 \%$ of fly ash and $1.5 \%, 3 \%, 4.5 \%$ of Nano-silica and respectable weights are illustrated in the above table no 4.2.

\section{Results and Discussions}

\subsection{General}

Tests were led on solidified solid examples to acquire the compressive quality, split rigidity, flexural quality and modulus of versatility. Standard systems were received for testing.

\subsection{Discussion of the Results}

The consequences of the trial examinations are displayed and talked about in this. The exploratory project was intended to analyze the properties of compressive quality of solid shapes and barrels, flexural quality, part rigidity and modulus of flexibility of M25 evaluation concrete and with distinctive substitution levels of conventional Portland bond (Ultratech bond 43 grade) with fly cinder, nano-silica and the blend of fly fiery remains and nano-silica.

\subsection{Compressive Strength}

The test consequences of compressive quality of M25 evaluation concrete with vanous extents of fly powder and nano-silica is appeared in Table6.1. The variety of compressive quality of M25 evaluation concrete with distinctive rates of fly powder and fluctuating rates of nanosilica is appeared in Figure 6.1.

The solid shape compressive quality demonstrates the normal of three test outcomes. It can be watched that the compressive quality of cement arranged utilizing fly slag and nano-silica displays more quality than the control concrete up to $3 \%$ of nano-silica if the rate of fly fiery remains is $20 \%$ and with further increment in nano-silica the compressive quality reductions. In any case, if the rate of fly cinder is expanded to $30 \%$ regardless of the substance of nano-silica the compressive quality is not exactly the control concrete. 


\section{International Journal of Science and Research (IJSR) \\ ISSN (Online): 2319-7064}

Index Copernicus Value (2013): 6.14 | Impact Factor (2015): 6.391

Table 6.1: Cube Compressive Strengths ofM25 Grade Concrete

\begin{tabular}{|c|c|c|c|c|c|c|}
\hline \multirow{3}{*}{ Concrete Mix } & \multirow{3}{*}{ FA $(\%)$} & \multirow{3}{*}{ NS (\%) } & \multirow{2}{*}{\multicolumn{4}{|c|}{$\frac{\text { Compressive Strength (MPa) }}{\text { DAYS }}$}} \\
\hline & & & & & & \\
\hline & & & 3 & 7 & 28 & 56 \\
\hline Control Concrete & 0 & 0 & 20.80 & 22.40 & 32.10 & 33.50 \\
\hline FA20 $\%+\mathrm{NSO} \%$ & 20 & 0 & 15.90 & 18.20 & 27.50 & 28.50 \\
\hline FA $20 \%+$ NS $1.5 \%$ & 20 & 1.5 & 17.50 & 20.10 & 29.10 & 31.40 \\
\hline FA20 \%+NS 3\% & 20 & 3 & 21.10 & 23.40 & 34.10 & 36.90 \\
\hline FA $20 \%+$ NS $4.5 \%$ & 20 & 4.5 & 17.40 & 21.10 & 31.60 & 33.10 \\
\hline FA30\%+NS $0 \%$ & 30 & 0 & 14.10 & 16.90 & 25.60 & 29.00 \\
\hline FA $30 \%+$ NS $1.5 \%$ & 30 & 1.5 & 15.30 & 18.10 & 26.50 & 29.20 \\
\hline FA30\%+NS3\% & 30 & 3 & 17.20 & 19.70 & 28.00 & 31.10 \\
\hline FA $30 \%+\mathrm{NS} 4.5 \%$ & 30 & 4.5 & 14.60 & 18.40 & 26.50 & 29.00 \\
\hline
\end{tabular}

FA=Fly Ash, NS=Nano Silica

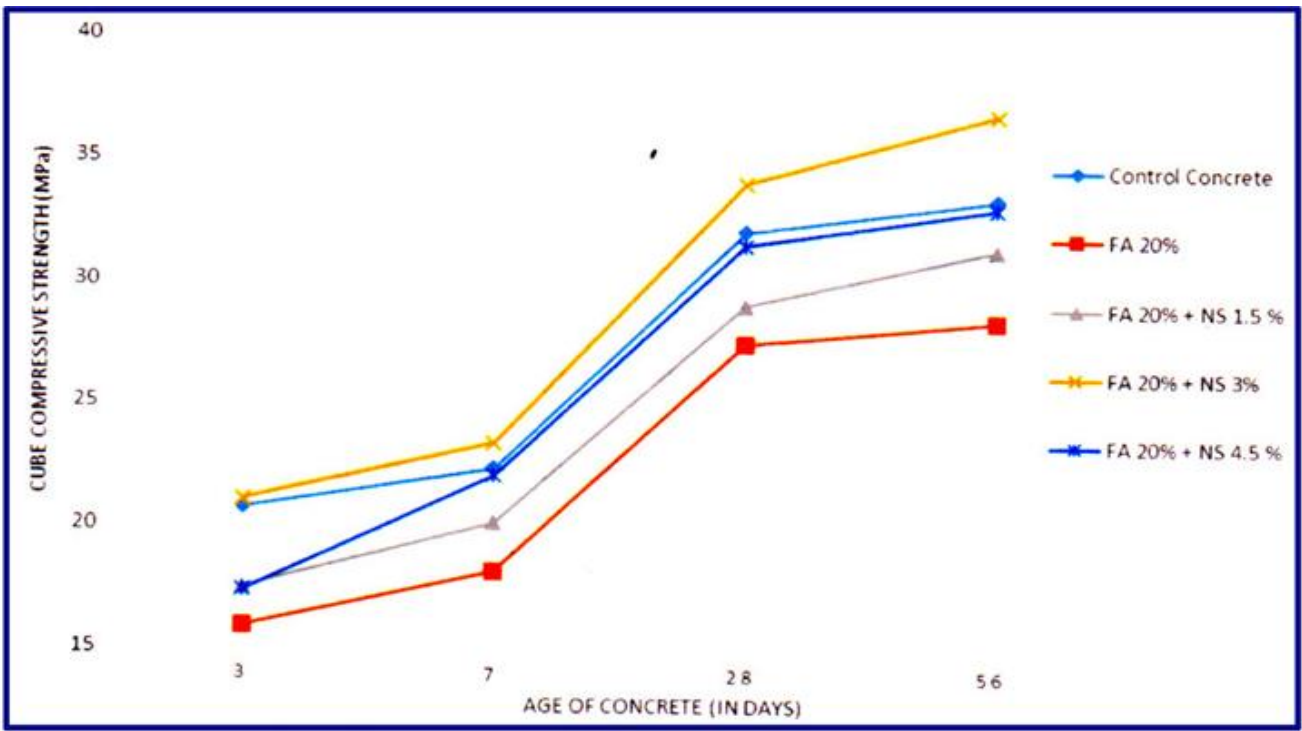

i) $20 \%$ Fly Ash

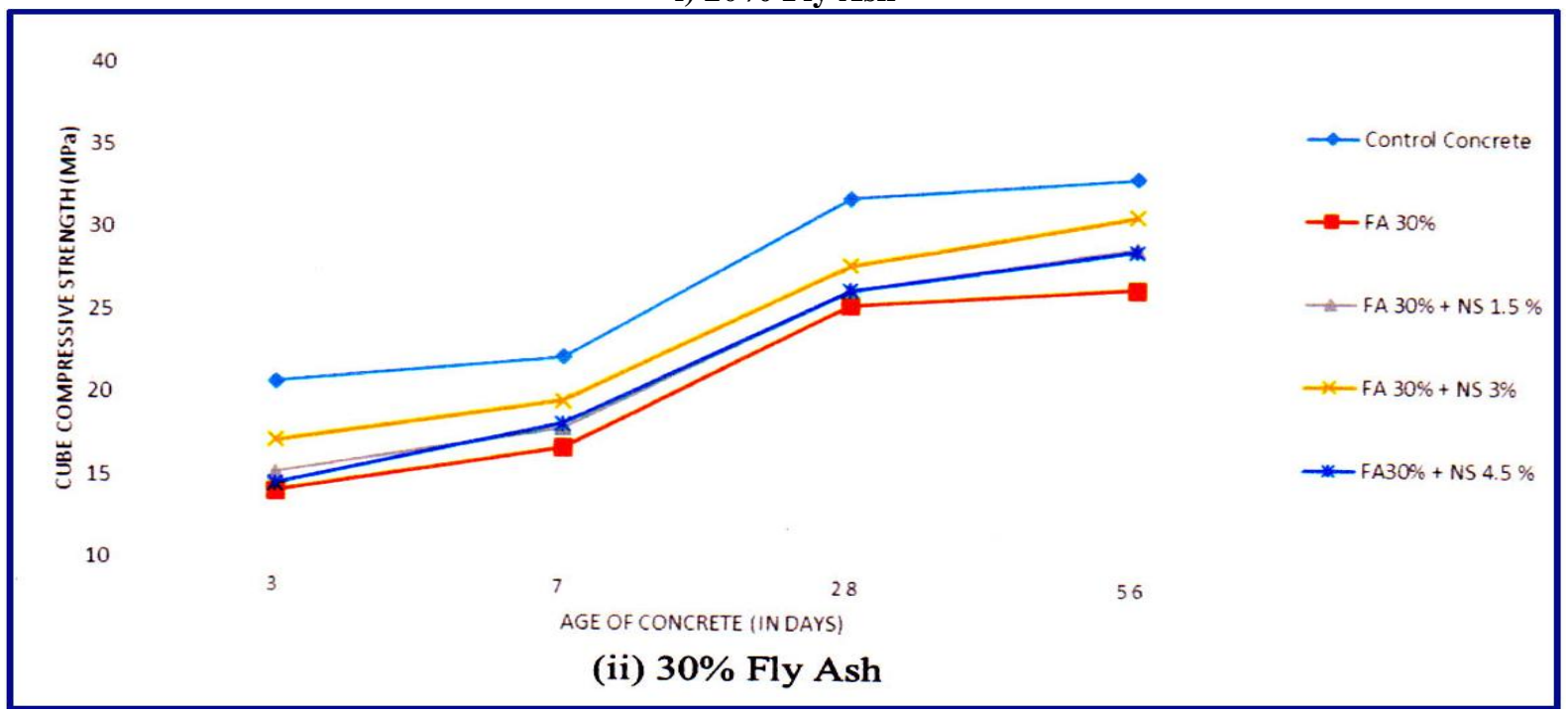

Figure 6.1:Variation of Cube Compressive Strength of M25 Grade Concrete with Age for Different Percentages of Fly Ash and Nano-Silica

Variation of 7 days and 28 days cube compressive strength

The variety of 7 days and 28 days 3D square compressive quality of M25 evaluation of cement with distinctive extents of nano-silica and fly powder is appeared in Fig 6.2. The compressive quality of cement at first increments up to $3 \%$ nano-silica andafterward the quality reductions with further increment in nano-silica for $20 \%$ and $30 \%$ of fly cinder substance. The 7 days and 28 days solid shape compressive quality of control cement is $22.37 \mathrm{MPa}$ and $32.12 \mathrm{MPa}$ individually. The expansion in 7 days and 28 days solid shape compressive strength of concrete with $3 \%$ nano-silica and $20 \%$ fly powder mix is $4.6 \%$ and $6.1 \%$ individually.

\section{Volume 5 Issue 6, June 2016} www.ijsr.net 


\section{International Journal of Science and Research (IJSR) \\ ISSN (Online): 2319-7064}

Index Copernicus Value (2013): 6.14 | Impact Factor (2015): 6.391

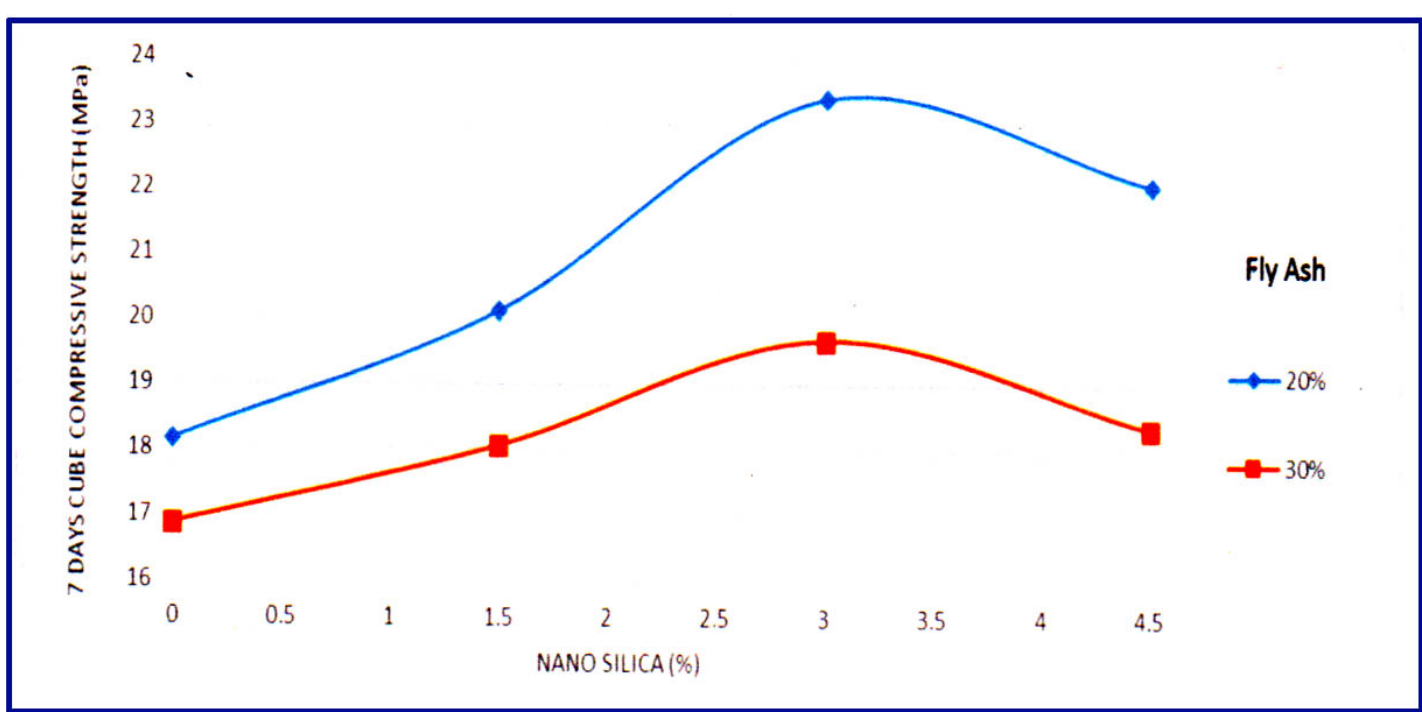

(i) 7 days Cube Compressive Strength

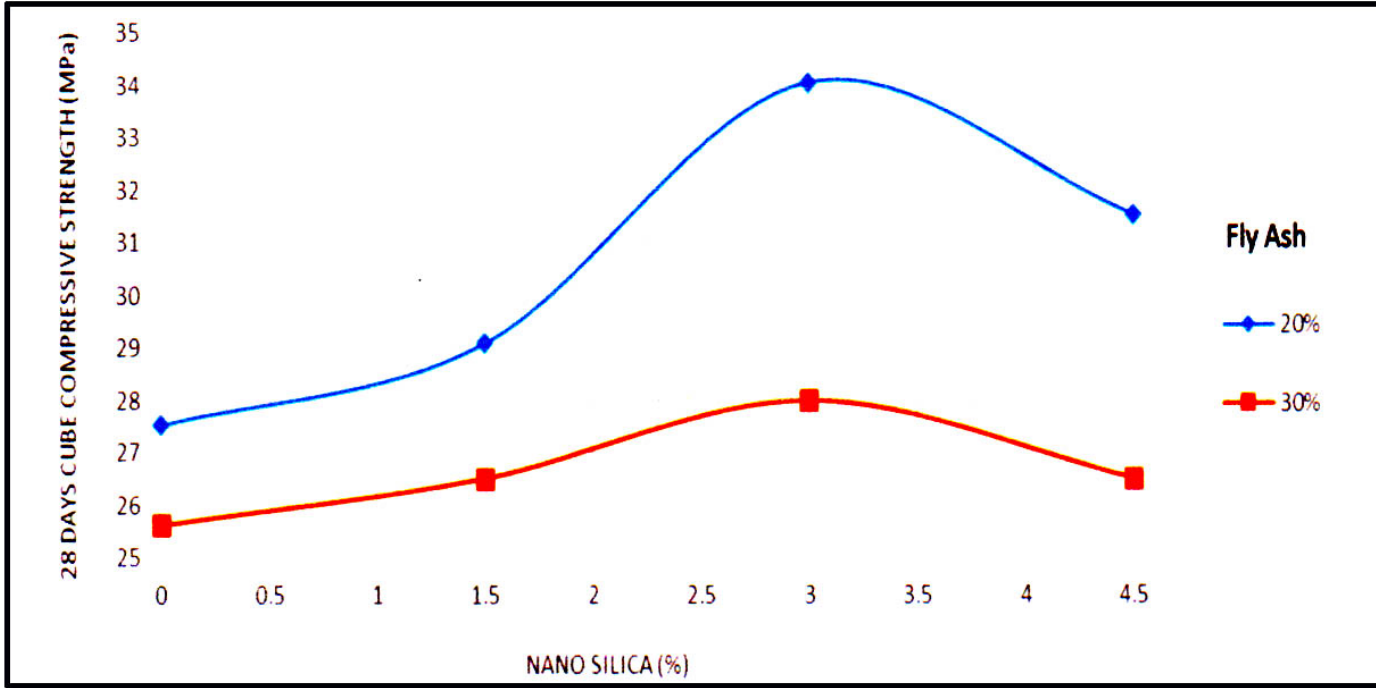

(ii) 28 days Cube Compressive Strength

Figure 6.2: Variation of Cube Compressive Strength ofM 25 Grade of Concrete with Nano-Silica for various percentages of Fly Ash

Examination is likewise made between the 3D square compressive quality and barrel shaped compressive quality of cement containing different rates of fly fiery debris and nano-silica mix at 28 years old days. The test outcomes are appeared in Table 6.2. The proportion of solid shape compressive quality and barrel compressive quality is observed to be around 0.88

Table 6.2: Comparison between 28 days Cube and Cylinder Compressive Strength of Concrete Prepared with Fly Ash (FA) and Nano-Silica (NS)

\begin{tabular}{|c|c|c|c|c|}
\hline S.No. & Concrete & $\begin{array}{c}\text { Cube Compressive Strength (MPa) } \\
\sigma_{\text {Cylinder }}\end{array}$ & $\begin{array}{c}\text { Cylinder Compressive Strength } \\
(\mathrm{MPa}) \sigma_{\text {Cylinder }}\end{array}$ & $\sigma_{\text {Cylinder }} / \sigma_{\text {Cube }}$ \\
\hline 1. & Control Concrete & 32.12 & 27.36 & 0.85 \\
\hline 2. & FA20\%+NSO $\%$ & 27.53 & 24.50 & 0.89 \\
\hline 3. & FA 20 $\%+$ NS 1.5 $\%$ & 29.10 & 25.90 & 0.89 \\
\hline 4. & FA 20\%+ S3 \% & 34.07 & 30.66 & 0.90 \\
\hline 5. & FA 20\%+NS 4.5\% & 31.55 & 27.76 & 0.88 \\
\hline 6. & FA30\%+NS 0 \% & 25.62 & 21.88 & 0.85 \\
\hline 7. & FA 30 $\%+$ NS 1.5\% & 26.51 & 22.83 & 0.86 \\
\hline 8. & FA30\%+NS3\% & 28.00 & 24.32 & 0.87 \\
\hline 9. & FA 30\%+ NS 4.5\% & 26.51 & 23.85 & 0.90 \\
\hline
\end{tabular}

\subsection{Split Tensile Strength}

The test aftereffects of split elasticity of M25 evaluation concrete with different extents of fly fiery debris and nanosilica is appeared in Table6.3. The variety of split rigidity of
M25 evaluation concrete with distinctive rates of fly fiery debris and changing rates of nano-silica is appeared in Figure 6.3.

\section{Volume 5 Issue 6, June 2016} www.ijsr.net 


\section{International Journal of Science and Research (IJSR) \\ ISSN (Online): 2319-7064 \\ Index Copernicus Value (2013): 6.14 | Impact Factor (2015): 6.391}

The split elasticity of control cement is $3.73 \mathrm{MPa}$. The split elasticity of cement at first expanded up to $3 \%$ of nano silica for the given rate of fly fiery debris and past which the split rigidity diminishes with expansion in the nano-silica. It can likewise be watched that at a mix of $3 \%$ of nano-silica and $20 \%$ fly cinder blend greatest split elasticity can be gotten. The expansion in split rigidity of cement with $3 \%$ nanosilica and $20 \%$ fly fiery debris substance is $3 \%$.
Table 6.3: Split Tensile Strengths of M25 Grade of Concrete

\begin{tabular}{|c|c|c|c|}
\hline Concrete Mix & $\begin{array}{c}\text { FA } \\
(\%)\end{array}$ & $\begin{array}{c}\text { Colloidal } \\
\text { Nano Silica } \\
(\%)\end{array}$ & $\begin{array}{c}\text { Split Tensile } \\
\text { Strength (MPa) for } \\
\text { 28 Days }\end{array}$ \\
\hline Control Concrete & 0 & 0 & 3.73 \\
\hline FA20\%+NSO $\%$ & 20 & 0 & 3.29 \\
\hline FA 20\%+ NS 1.5 \% & 20 & 1.5 & 3.48 \\
\hline FA20\%+ NS 3\% & 20 & 3 & 3.84 \\
\hline FA 20\%+NS 4.5 \% & 20 & 4.5 & 3.52 \\
\hline FA30\%+NSO\% & 30 & 0 & 3.15 \\
\hline FA 30\%+ NS 1.5 \% & 30 & 1.5 & 3.30 \\
\hline FA30\%+NS3\% & 30 & 3 & 3.60 \\
\hline FA30\%+NS4.5 \% & 30 & 4.5 & 3.40 \\
\hline
\end{tabular}

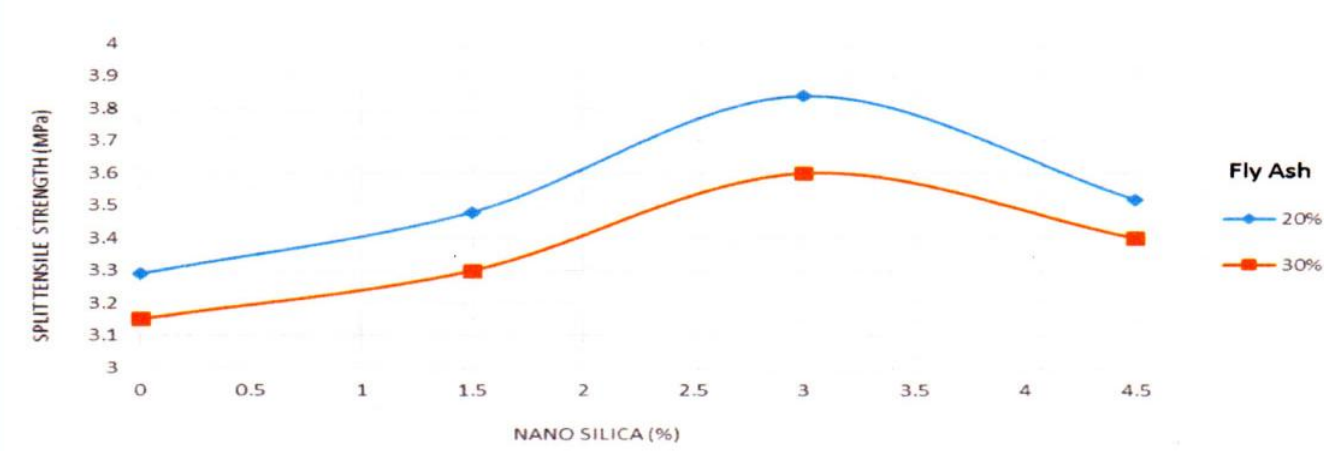

Figure 6.3: Variation of Split Tensile Strength of M25 Grade of Concrete with different percentages of Nano-Silica and Fly Ash

\subsection{Flexural Strength}

The test aftereffects of flexural quality of M25 evaluation concrete with different extents of fly cinder and nano-silica is appeared in Table 6.4. The variety of flexural quality of M25 evaluation concrete with distinctive rates of fly fiery debris and fluctuating rates of nano-silica is appeared in Figure 6.4.

The flexural quality of control cement is 5.03 MPa. The variety of flexural quality of cement at first increments up to $3 \%$ rate of nano-silica for distinctive rate of fly fiery remains and after that with further increment in the nano-silica the flexural quality declines. The suggested mix for most extreme split elasticity is $3 \%$ of nano-silica and $20 \%$ fly fiery remains. The expansion in the flexural quality cement with $3 \%$ nano-silica and $20 \%$ fly fiery debris content contrasted with control cement is $3.4 \%$.

Table 6.4: Flexural Strengths of M25 Grade of Concrete

\begin{tabular}{|c|c|c|c|}
\hline Concrete Mix & $\begin{array}{c}\text { FA } \\
(\%)\end{array}$ & $\begin{array}{c}\text { Colloidal } \\
\text { Nano } \\
\text { Silica } \\
(\%)\end{array}$ & $\begin{array}{c}\text { Flexural } \\
\text { Strength }(\mathrm{MPa}) \\
\text { for28 Days }\end{array}$ \\
\hline Control Concrete & 0 & 0 & 5.03 \\
\hline FA20\%+NSO $\%$ & 20 & 0 & 4.42 \\
\hline FA 20\%+NS 1.5 \% & 20 & 1.5 & 4.63 \\
\hline FA 20\%+NS3 \% & 20 & 3 & 5.20 \\
\hline FA 20\%+NS 4.5 \% & 20 & 4.5 & 4.80 \\
\hline FA30\%+NSO $\%$ & 30 & 0 & 4.14 \\
\hline FA 30 \%+ NS 1.5 \% & 30 & 1.5 & 4.33 \\
\hline FA30\%+NS3\% & 30 & 3 & 4.51 \\
\hline FA30\%+NS4.5 \% & 30 & 4.5 & 4.26 \\
\hline
\end{tabular}

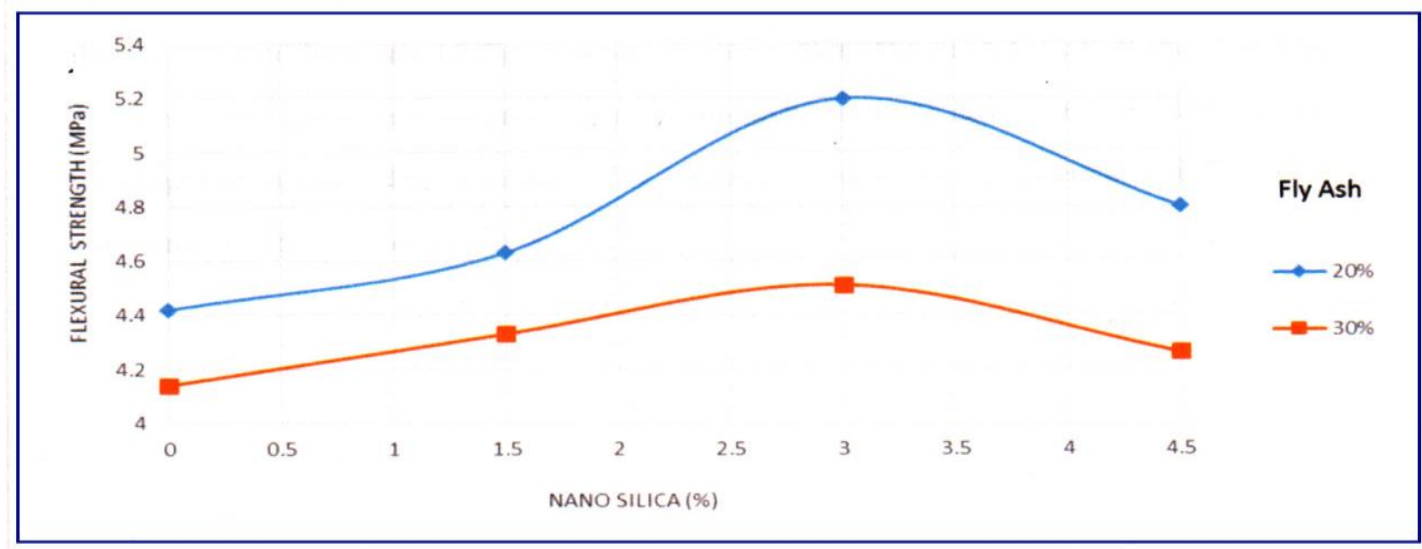

Figure 6.4: Variation of Flexural Strength of M25 Grade of Concrete with Different Percentages of Nano-Silica and Fly Ash

Volume 5 Issue 6, June 2016 www.ijsr.net 


\section{International Journal of Science and Research (IJSR) \\ ISSN (Online): 2319-7064}

Index Copernicus Value (2013): 6.14 | Impact Factor (2015): 6.391

\subsection{Modulus of Elasticity}

The test consequences of modulus of versatility of M25 evaluation concrete with different extents of fly fiery debris and nano-silica is appeared in Table6.5. The variety of modulus of flexibility of M25 evaluation concrete with distinctive rates of fly fiery debris and fluctuating rates of nano-silica is appeared in Figure 6.5.

It can be watched that the modulus of versatility of solid increments with nano-silica for the given substance of fly cinder. The most extreme quality is gotten at 3\% nano-silica for the given substance fly fiery debris.

The M25 grade control concrete has modulus of flexibility of $24.90 \mathrm{GPa}$. The vicinity of $20 \%$ fly fiery remains the modulus of flexibility is diminished to $22.82 \mathrm{GPa}$ and with $30 \%$ fly cinder the quality is further diminished to 22.27 $\mathrm{GPa}$. The modulus of versatility of fly slag solid increments in the vicinity of nano-silica. The modulus of flexibility of M25 evaluation concrete accomplishes greatest quality at a mix of $3 \%$ nano-silica and $20 \%$ fly powder by weight of bond. The expansion in the modulus of flexibility of cement with $3 \%$ nano-silica and $20 \%$ fly fiery remains substance is $3.1 \%$.

Table 6.5: Modulus of Elasticity of M25 Grade of Concrete

\begin{tabular}{|c|c|c|c|}
\hline Concrete Mix & FA & $\begin{array}{c}\text { Colloidal } \\
\text { Nano } \\
\text { Silica (\%) }\end{array}$ & $\begin{array}{c}\text { Modulus of } \\
\text { Elasticity } \\
\text { (GPa) for 28 } \\
\text { Days }\end{array}$ \\
\hline Control Concrete & 0 & 0 & 24.90 \\
\hline FA20\%+NSO\% & 20 & 0 & 22.82 \\
\hline $\begin{array}{c}\text { FA 20\%+ NS } \\
1.5 \%\end{array}$ & 20 & 1.5 & 23.73 \\
\hline FA20\%+NS3\% & 20 & 3 & 25.68 \\
\hline $\begin{array}{c}\text { FA 20\%+ NS } \\
4.5 \%\end{array}$ & 20 & 4.5 & 24.71 \\
\hline FA30\%+NS 0\% & 30 & 0 & 22.27 \\
\hline $\begin{array}{c}\text { FA 30 } \%+\text { NS } \\
1.5 \%\end{array}$ & 30 & 1.5 & 22.65 \\
\hline FA30\%+NS 3\% & 30 & 3 & 23.28 \\
\hline $\begin{array}{c}\text { FA 30\%+ NS } \\
4.5 \%\end{array}$ & 30 & 4.5 & 22.65 \\
\hline
\end{tabular}

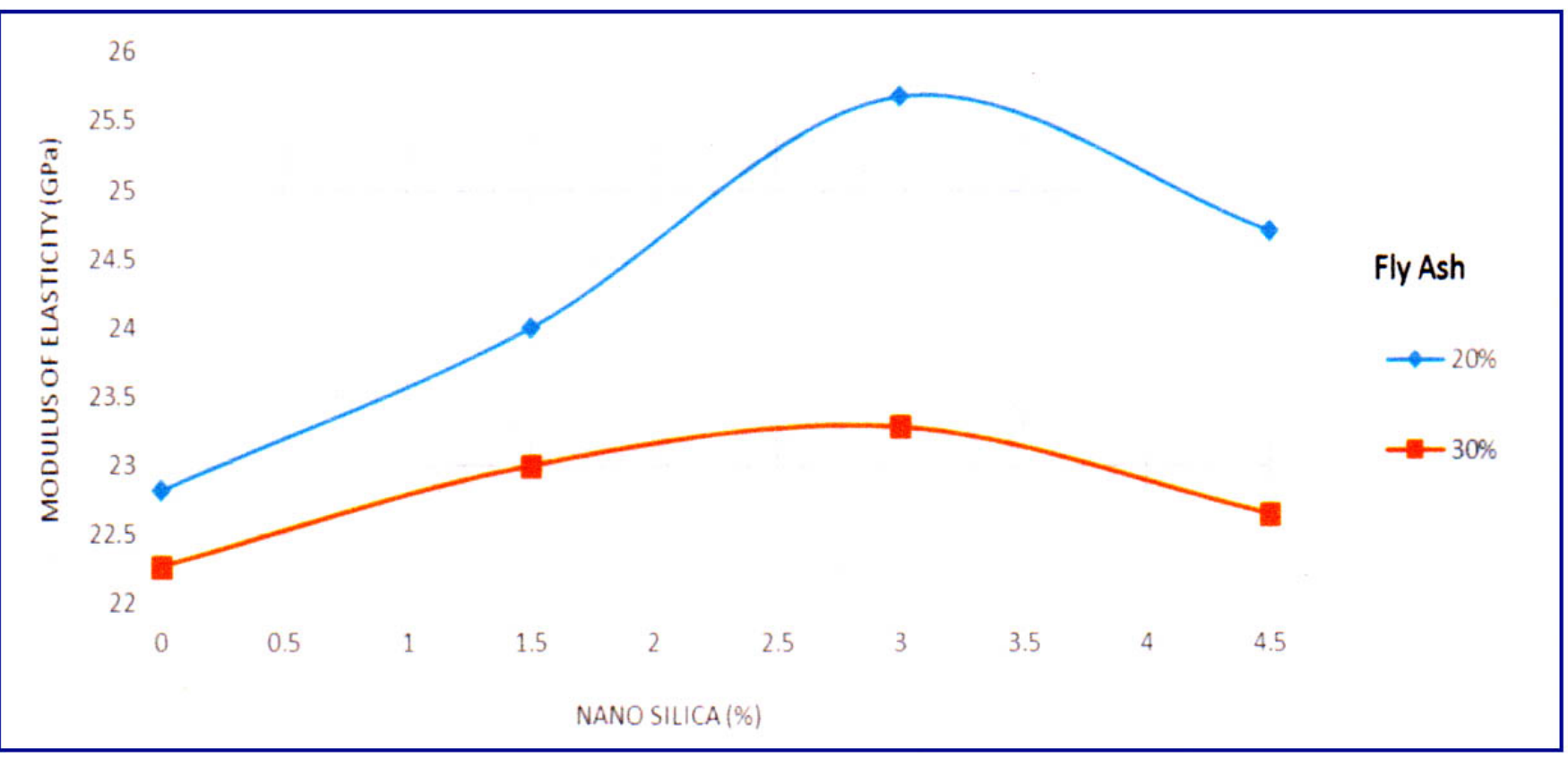

Figure 6.5: Variation of Modulus of Elasticity of M25 Grade of Concrete with Nano-Silica for different percentages Fly Ash

\section{Conclusions}

\subsection{Conclusions}

The after effects of the test examination demonstrate that the blend of fly fiery debris and nano-silica can be utilized as Ordinary Portland bond substitution for solid readiness.

1) Using the test outcomes, it can be inferred that with the expansion in the rate of nano-silica for distinctive rates of fly slag, the different quality properties of cement are expanded up to $3 \%$ of nano silica and with further increment in the nano-silica, the properties of cement are diminished.

2) It is extremely intriguing to note that the variety of compressive quality, split rigidity, flexural quality and modulus of versatility of M25 review fly fiery remains concrete with different rates of nano-silica shows the comparable pattern.

3) The expansion in different quality properties of cement containing fly fiery debris with expansion in the nanosilica substance can be because of the accessibility of extra cover in the vicinity of nano-silica. The nano silica and fly fiery remains responds with the calcium hydroxide to shape extra cover material. The accessibility of extra cover prompts increment in the binding material, results in enhanced quality properties of the solid arranged with nano-silica and fly fiery remains mix.

4) The reduction in the quality attributes of cement with expansion in the nano-silica content past $3 \%$ is because of the low quality of cover shaped in the vicinity of high substance of nano-silica and fly cinder. 


\section{International Journal of Science and Research (IJSR) \\ ISSN (Online): 2319-7064}

Index Copernicus Value (2013): 6.14 | Impact Factor (2015): 6.391

5) The different quality attributes of cement can be enhanced by the joint utilization of $3 \%$ nano-silica and $20 \%$ fly fiery debris content. It can likewise be inferred that the bond substance can be lessened without trading off the quality of cement by the utilization of fly cinder and nano-silica blend.

\subsection{Scope of Future Work}

The impact of nano-silica and fly fiery debris can be examined on strength properties of cement. The effect of resistance of nano-silica and fly fiery debris can likewise be decided.

\section{References}

[1] Belkowitz,J. and Armentrout, D. L. (2009). The Investigation of ano Silica ill the Cement Hydration Process. ACI Special Publication 267(8): 87 -100.

[2] Bentz. D.P et al.,(2010),"Evaluation of sustainable high volume fly ash concretes, Cement and Concrete Composites, Vol 33, pp 39-45.

[3] Carette .G et.al. (2010),"Strength development of concrete incorporating fly ash".Materials, VoL. 90(6), pp.535-544.

[4] Freeda Christy .C and D Tensing. (20 I 0). "Effect of Class F Fly Ash as Partial Replacement with cement" IJEMS, Vol 17 pp 140 - 144

[5] Gengying Li., (2004). "Properties of High-Volume Fly Ash Concrete incorporating ano- $\mathrm{SiO}_{2}$, Cement and Concrete Research, pp. 1043-1049.

[6] IS 516: 1959. "Methods of Tests for Strength of Concrete". Bureau of Indian Standards, New Delhi, India.

[7] IS: 10262-2009. Concrete Mix Proportioning Guidelines (First Revision). Bureau of Indian Standards, New Delhi.

[8] IS: 383:1970 (Reaffirmed 1997) Specification for Coarse and Fine Aggregates from Natural Sources for Concrete. Bureau of Indian Standards, New Delhi. .

[9] IS: 8112: 1989. "43 Grade Ordinary Portland Cement Specifications". Bureau of Indian Standards, New Delhi.

[10] Jagadesh.Sunku (2006)," had studied the advantages of use of fly ash as Supplementary Cementing Materials in Fibre cement sheets. International Inorganic Bonded Fibre Composites Conference, pp.25-32.

[11] Kazim Turk et.al. (2012)," The effect of fly ash and silica fume on Compressive Strength". Construction and Building Materials, Vol 37,pp.326-334.

[12] Quercia .G and H.I.H. Browwers, (2010). 'Applications of ano Silica 111 Concrete Mixtures', 8th Ph.D. Symposium in Kg Lyngby, Denmark, June 20-23,

[13] Sanchez,F., and Sobolev, K. (2010). "Nano-Technology in Concrete - A Review", Construction and Building Materials. 24, 2060-2071.

[14] Surendra P. Shah, et al. (2010). "Controlling Properties of Concrete through Nano Technology" Proc. of the International Conference on Advances in Concrete, ICIACECO 2010,5-9 Dec., IIT, Madras, India, PP 1-8.

[15] Thomas et al., (1999), "Reported that fly ash reduced concrete strength at early ages, but significantly enhanced strength at later ages". Cement and Concrete Research, Vol 29(4), pp.487-495.

[16] VanithaAggarwalet.al., (2010),"Concrete durability through high volume Fly Ash concrete. International Journal of Engineering Science and Technology, Vol 2(9), pp.4473-4477. 